\author{
Abstracta Iranica \\ Abstracta Iranica Revue bibliographique pour le domaine irano-aryen \\ Volume 32-33 | 2013 \\ Comptes rendus des publications de 2009-2010
}

\title{
Christelle Jullien. Christianiser le pouvoir. Images de rois sassanides dans la tradition syro-orientale
}

\section{Rédaction}

\section{(2) OpenEdition \\ 12 Journals}

\section{Édition électronique}

URL : http://journals.openedition.org/abstractairanica/40526

DOI : 10.4000/abstractairanica.40526

ISSN : 1961-960X

Éditeur :

CNRS (UMR 7528 Mondes iraniens et indiens), Éditions de l'IFRI

\section{Édition imprimée}

Date de publication : 1 décembre 2013

ISSN : 0240-8910

Référence électronique

Rédaction, «Christelle Jullien. Christianiser le pouvoir. Images de rois sassanides dans la tradition syroorientale », Abstracta Iranica [En ligne], Volume 32-33 | 2013, document 177, mis en ligne le 01 juin 2016, consulté le 03 octobre 2020. URL : http://journals.openedition.org/abstractairanica/40526 ; DOI : https://doi.org/10.4000/abstractairanica.40526

Ce document a été généré automatiquement le 3 octobre 2020.

Tous droits réservés 


\section{Christelle Jullien. Christianiser le pouvoir. Images de rois sassanides dans la tradition syro-orientale}

\section{Rédaction}

\section{RÉFÉRENCE}

Christelle Jullien. « Christianiser le pouvoir. Images de rois sassanides dans la tradition syro-orientale ». Orientalia christiana periodica 75/1, 2009, p. 119-131.

1 Pour l'époque sassanide, dans la communauté syro-orientale de l'empire iranien, se met en place tout un processus d'élaborations hagiographiques des souverains en rois éclairés et ouverts, voire même chrétiens. Grâce à une mise en contexte historique, l'A. explicite les intentions de ces pratiques d'écriture et les volontés politiques des autorités chrétiennes.

\section{AUTEURS}

\section{RÉDACTION}

Direction de la revue et secrétariat (Paris) 